濃度を測定し，腎臓の濃縮機能を調査した。ま た対照として22例の青，壮年者を選び，両者を 比較検討した。濃縮機能を表す諸因子のうち, 老人の尿最高渗透圧濃度及び渗透圧のクリアラ ンスは対照例の約 $1 / 2$ であり，遠位側水再吸収 極量は，負荷した抗利尿ホルモンに反応して， 対照者では系球体濾過値を 100 とした場合 6 を 越えるが，老人の場合には反応性は存在しても 5 を越光ない。即ち水再吸収率の上界に明らか
な低下が認められる。これら濃縮機能の低下の 原困は尿細管細胞自体の機能低下と同時に, 腎 血行力学上の变化による溶質転送機転の障害が 主体であろうと推察する。

終るに臨み, 今回の調查に御協力下さつた浴風園尼 子富士郎博士, 東大冲中内科柴田整一講師等に深く感 謝の意を表する。

\title{
4. 老人の腎機能
}

\section{まえがき}

年令と腎機能に関しては Lewis， Alving， Shock, Watkin, Davis, 大島, 沢田, 王子, 田坂，その他多数の報告がある。そして，種々 の腎機能を年令の一次函数として回帰方程式を 提示している人もあるくらいであつて，腎機能 は年令と共に相当規則正しく低下するとされて いて，年令と腎機能に関しては，今更多く附け 加える余地を残していないように思われるくら いである。私達の研究に於ても嘗つて昭和 32 年に第 2 回日本 Gerontology 学会で報告した ように糸球体濾過值，尿素クリアランス，尿濃 縮力, PSP 排泄試験, 腎血漿流量及び腎血流 量などの減少, 濾過率, 血漿残余窒素などの上 犁の様子は，内外諸家の成績と大体同様の成績 を得ており，腎機能はいずれも年令と共に徐々 に低下し, 殊に 50 才前後から機能の低下の程 度が著明となるようである。そこで今回は観点 を変光て，或る集団に拈ける老年者全体を対象 として，即ち，一応自覚的には健康者として生 活しているが，精査すれば諸種の疾患を有する ものが混在している樣な老人の集団を対象とし

\section{九州大学助教授 井 村 棲 梧}

て, 後述の様な種々の検査を行つてそれら身体 諸徵候との関連において, 老人では腎機能がど の様になつているかを検討してみた。

1. 対象：福岡市の東方近郊にある須恵町 を選び, その町の 65 才以上の男子を対象とし た。この町の 65 才以上の老年者の人口は昭和 35 年国勢調査によれば第 1 表の如く, 全国並 に福岡県の平均をむしろ下廻る老年者構成の町 であつて, 言わば普通一般の町であつて, 決し て所謂長寿命村というような特殊な町を選んだ のではない。

第 1 表

\begin{tabular}{|c|c|c|c|c|}
\hline & & 男 & 女 & 計 \\
\hline \multirow[t]{2}{*}{ 全 } & 総人口 & \multicolumn{3}{|c|}{$45,819,50047,527,700$} \\
\hline & $\begin{array}{c}65 才 以 上 ~ \\
(\%)\end{array}$ & $\begin{array}{l}2,342,000 \\
(5.11)\end{array}$ & $\begin{array}{l}3,043,000 \\
\quad(6.40)\end{array}$ & $\begin{array}{c}5,385,000 \\
(5.77)\end{array}$ \\
\hline \multirow{2}{*}{$\begin{array}{l}\text { 福 } \\
\text { 岡 } \\
\text { 県 }\end{array}$} & 総人口 & $1,933,600$ & $2,033,800$ & $3,967,600$ \\
\hline & $\begin{array}{c}65 \text { 才以上 } \\
(\%)\end{array}$ & $\begin{array}{c}93,400 \\
(4.84)\end{array}$ & $\begin{array}{l}119,200 \\
(5.86)\end{array}$ & $\begin{array}{l}211,400 \\
(5.33)\end{array}$ \\
\hline \multirow{2}{*}{$\begin{array}{l}\text { 須 } \\
\text { 恵 } \\
\text { 町 }\end{array}$} & 総人口 & 7,617 & 8,024 & 15,641 \\
\hline & $\underset{(\%)}{65 \text { 才以上 }}$ & $(3.72)^{285}$ & $(5.11)^{410}$ & $(4.21)^{698}$ \\
\hline
\end{tabular}


検査項目及び検査方法：検査前日の夕食以 後は一切の领食を禁じ，検査当日の朝排尿させ， 朝食を摂らずに朝 8 時に採尿させて，その尿を 検査場に持参させた。この尿について比重を測 定し, 腎濃縮力の指標とした, 次に検査場に於 ては，身長，体重を計測した後，水500ccをの ませて若干時間後採层して膀脱を空虚ならしめ た。この㽷については, 蛋白, 糖, ウロビリ, ーゲンの定性試験を行つた。この採尿から正確 に 1 時間目に採尿し，このクレアチニンを定量 した。なお,この 1 時間の間に問診, 一般診察, 心電困検查, 血圧測定, 指端血液量測定, 血色 素量などを測定し，また採尿と採尿の略々中間， 則ち上記採尿から約 30 分頃に肘静脈から採血 して, この血中のクレアチニン, 尿素, 残余窒 素などを計り，上記の尿中のクレアチニン量と 併せて，1時間法による 1 分間クレアチニンク リアランスを算出し, 更に血液の一部を以つて, コレステロール, 黄疸指数, クンケル, GOT,

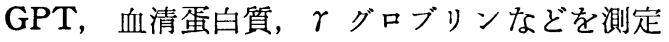
して肝機能検査にあてた。更に若干時間後に $0.6 \%$ PSP $1.0 \mathrm{cc}$ を静注して正確に15 分後に 採尿し, PSP 15 分間排泄量を求めた。

次に検査第 2 日には同椂に朝食を禁じ BSP 検査（45分值）を行い，それがすんで引続き無 胃管法による胃液酸度測定を行つた。なお，こ の日の大便を持参せしめて, これにつき, 潜血 反応と寄生虫卵の有無を検した。

この検査に拉ける受診率とその年令分布は第 2 表の如くである。但しこれらのうち, 夜間排 尿が 3 回以上に及ぶものは指触診を行つて, 明 らかに前立腺肥大が認められるものは集計から 除き，その他採尿過誤などで明らかに実験過誤 を起したと認められるような例は集計から除外 した。

第 2 表 集団検診受診率

\begin{tabular}{|c|c|c|c|}
\hline & 男子人口 & 受診者 & 受 診 率 \\
\cline { 1 - 4 } 65 69才 & 123 & 42 & $34.1 \%$ \\
\hline 70 才以上 & 139 & 101 & $72.7 \%$ \\
\hline 合 計 & 262 & 143 & $54.6 \%$ \\
\hline
\end{tabular}

\section{2. 成績及び考按}

(1) 前回即ち第 2 回日本 Gerontology 学 会で報告した際には，65才以上の高令者の例数 が少なかつたので，今回はこの機会に先ず $65 才$ 以上の老年者の腎機能を年令別に追求してみた。

（i） 尿濃縮力 尿濃縮力は年令が進むにつ れて低下を来し，その回帰方程式は 1.04381 $0.00029 \times$ 年令 となり Lewis らの提示した回 帰曲線と大体同樣である。しかし，以下順次記 述する諸種腎機能についても同椂であるが我々 の今回の成績は極めてバラッキが多い。

(ii) PSP 15 分排泄量 これも年令と共に かなりきれいな相関をもつて低下するが，矢張 りバラッキが相当大きいことが認められる。年 令の一次函数と仮定して回帰曲線を求めてみる と，55.97-0.416×年令 なる式が得られた。

（iii） 系球体濾過值 内因性クレアチニンク リアランスをもつて系球体濾過值としてみると， 第 1 図の如くやはり年令と共に系球体濾過值が 下り，殊に 80 才代になると下降が著明である。

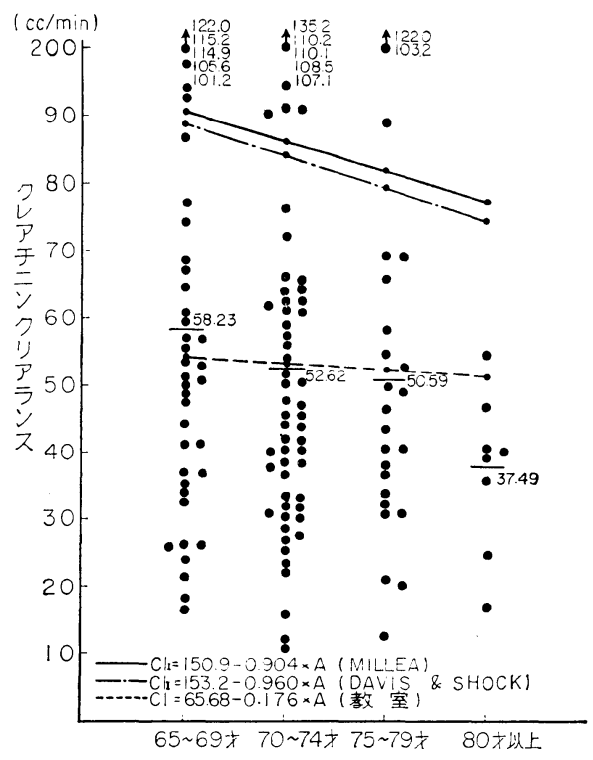

第 1 図老年者の系球体濾過値

その回帰方程式は $65.68-0.176 \times$ 年令 であつ て，イヌリンクリアランスを以つてするDavis \& Shock の 153.2-0.96×年令 なる方程式 や Miller らの 150.9-0.904×年令 などに 
くらべるとかなり低值である。

（iv）血中残余窒素及び血中尿素窒素 65 69才, 70〜74 才, 75〜79 才, 80 才以上のそ れぞれ血中残余窒素量の平均は $31.44 ， 32.23$, $33.30,42.5 \mathrm{mg} / \mathrm{d} l$, 血中尿素窒素量の平均は $15.80,16.12,17.25,27.42 \mathrm{mg} / \mathrm{d} l$ であつて, 上記クリアランスの低下に呼応して増量を来し, 殊に 80 才代になると上䄯が急になる。

（2）そこで，今度は腎機能相互の関係を求 めてみると，尿濃縮力と PSP 排泄量との間に は軽度な相関関係は認められるが，あまり高度 の相関を来すとは思われない。尿濃縮力とクレ アチニンクリアランスとの間の相関は更に稀薄 なようである。

（3）以上の如く, 各種腎機能は年令を加え ると共に漸次低下し，殊に 50 才過ぎると 80 才 頃に秒々急激に腎機能が低下寸る傾向がめる。

一方, 橋本らの報告を引用して腎の重量の変 化をみると，男子も女子も共に 50 才前後から 腎の重量がかなり急激に減少し, 腎機能の低下 と軌を一にしているようにみえる。

（4）腎以外の身体諸徵との関連に於ける腎 機能まえがきにも述べたように，心蔵，肝蔵， その他腎以外の身体諸徵との関連に於いて老人 の腎機能を考察してみると次の如くである。

（i）動脈硬化の度合と腎機能橈骨動脈 と前腕動脈とを触診して，明らかに動脈硬化の 高度な子のと, 動脈硬化の全く感知出来ないる のとその中間の三つに区分してみた。この両動 脈の硬化は相互には寧ろ反対の相関を示寸如く みられ，更に，これらの動脈硬化の顕著なもの とそうでないものとの腎機能には明らかな差異 を見出し得なかつた。

（ii）毛髪と腎機能皮膚血流々腎血流の 間には古来一種の相関があるようにいわれてい るので，毛髮の状沉と腎機能との間にも多少と も相関がありはしないかと検討してみたが，白 髮或は秃頭の程度と腎機能の間には殆んぞ何も 関連を見出すことが出来なかつた。

(iii) 職業と腎機能この町は炭坑夫と農 業と従事者と一般商業との三種の職業に比較的
明瞭に区別されているという特殊事情があるの で，これら多年の職業の差異が何か腎機能に差 異を生ぜしめることはないかと思つて集計して みたが，この職業の差によつて特に腎機能に差 異を認めるという成績は得られなかつた。

（iv）血圧と腎機能血圧と腎機能とは最 も深い関連が予想されたのであるが，実際に検 討を加えてみると，クレアチニンクリアランス は最高血圧，最低血圧のいずれともそれ汪ど明 確な関連を見出すことは出来なかつた。また PSP 15 分間排泄量と血圧との間にも深い関連 を見出さなかつた。

（v）血清コレステロールと腎機能 この 間にも一定の関連を見出し得なかつた。

（vi）指端血液量と腎機能 $\quad 100 \% \mathrm{Hb}$ 換算 指端血液量は心不全や肺気腫などの際には特殊 な傾向を示すが，腎機能との間には一定の関係 を認めなかつた。

（vii）心電図と腎機能 心電図に拈ける例 えば ST とか T とかというような個々の変 化と腎機能との間にはあまり平行関係が認めら れなかつたので，聊か無理な試みとは思われた が，心電図の種々の変化に仮に第 3 表のような 基準で加点してみて，その点数の総計と腎機能 との関係をみてみると，例えば第 2 図の如く最 第 3 表 心電図変化加点基準

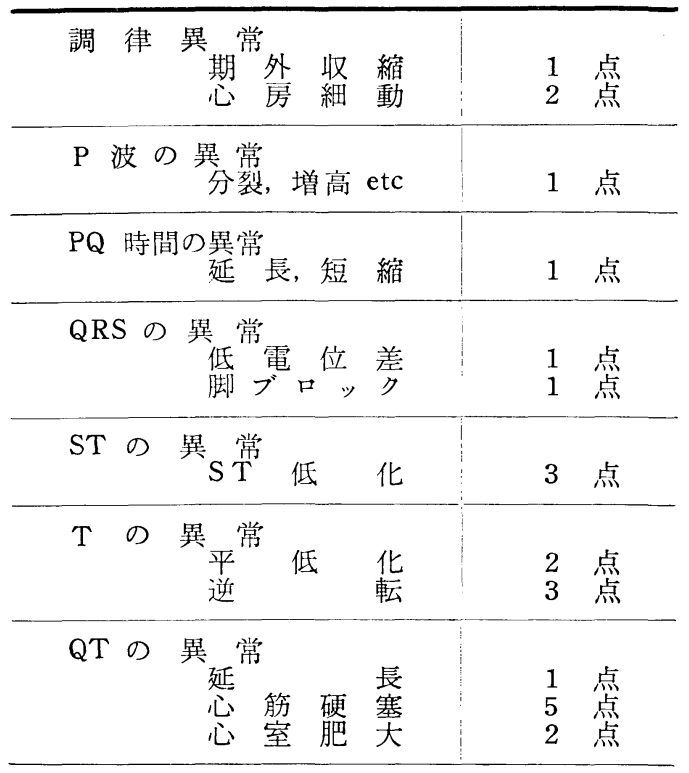




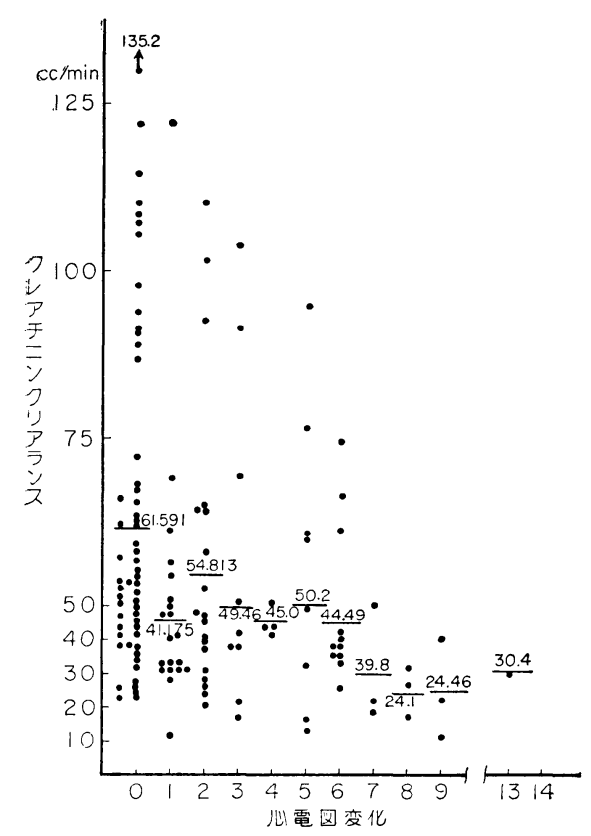

第 2 図心電図変化とクレアチニンクリアランス

も強い平行関係が認められた。

即ち, 心電図上種々の変化が同時に伴つてい るような例では加点の合計も大きいわけである が，このような例では，PSP 15 分間排泄量や クレアチニンクリアランスなどが低下している ような例が多いことが分つた。

(viii) 肝機能と腎機能従来とも, 肝・腎 の関連がよく言われているが，私達の例えば黄

第 4 表 肝機能加点基準

BSP 值は 2，5，8，10 以下をそれぞれ 1，2，3，4， 点とし 10 以上は 5 点とする。

黄庭指数は 8,15 以下をそれぞれ 1,2 点とし 15 以 上を 3 点とする。

クンケルは 10,12 単位以下を 1,2 点とし 12 単位 以上を 3 点とする。

GOT は 40, 50 以下を 1,2 点とし, 50 以上を 3 点 とする。

GPT は 35,50 以上を 1,2 点とし, 50 以上を 3 点 とする。

血清蛋白量は $7,6.5$ 以上を 1.2 点とし, 6.5 以下を 3 点とする。

rグロブリンは $20,25 \%$ 以下を 1,2 点とし， $25 \%$ 以上を 3 点とする。

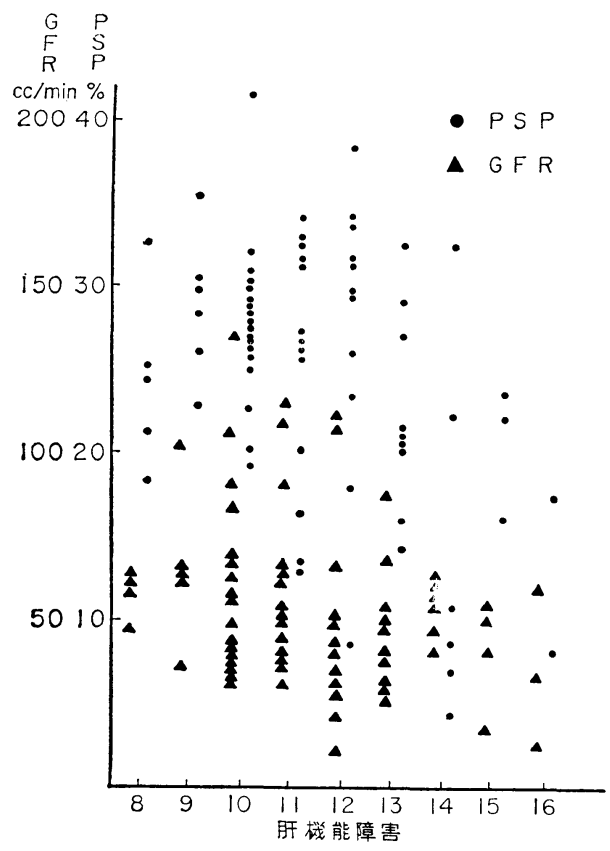

第 3 図 肝機能と PSP 及び GFR

㾝指数, BSP 試験, クンケル, 血清蛋白量, rグロブリン量, GOT, GPT, などのいずれと も，今回の成績では，個々の肝機能検査の成績, 婜機能との間には殆んど相関関倸は認められな かつた。ところが，仮にこれらの肝機能の各種 に第 4 表のような基準を設けて加点してみると その合計と腎機能, 例えば PSP 15 分間排泄量 やクレアチニンクリアランスとの間には第 3 図 の如くかなりの相関を示すようにみえた。

（ix）胃液酸度と腎機能老年者であるか ら低酸症のものが多かつたのは当然として，胃 液酸度の高い屯のと低酸或は無酸のものとの間 に腎機能の差異を見出し得なかつた。

（5）正常老年者の腎機能上記の如く各 種身体諸徵の個々と腎機能との間にはいずれも 強い関連が見られなかつたので，前記対象の中 から各種の検査で一つも病的所見を有しないる ののみを選別して，即ち言わば正常老年者のみ を抽出して，もう一度その腎機能と年令との関 係を再検討のてみると，クレアチニンクリアラ ンス, PSP 15 分間排泄量のいずれも年令と非 常に緊密な相関関係を認めることが出来た。 
このような点から考察すると, 腎機能は他の

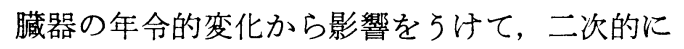
低下寸るというようなことは殆んどなく，むし ろ全身の諸藏器に終年的変化を来すような身体 状況になるとき，例えば全身の血管系の系統的
な老癈といらようなことを介して，腎機能も同 時に平行して低下寸るといらように考兄られる。

（6）老人の腎機能の位置 老人の腎機能 が生命保持上どの程度に位置するものかを考察 してみた。即ち, 私たちの教室にこれまで入院

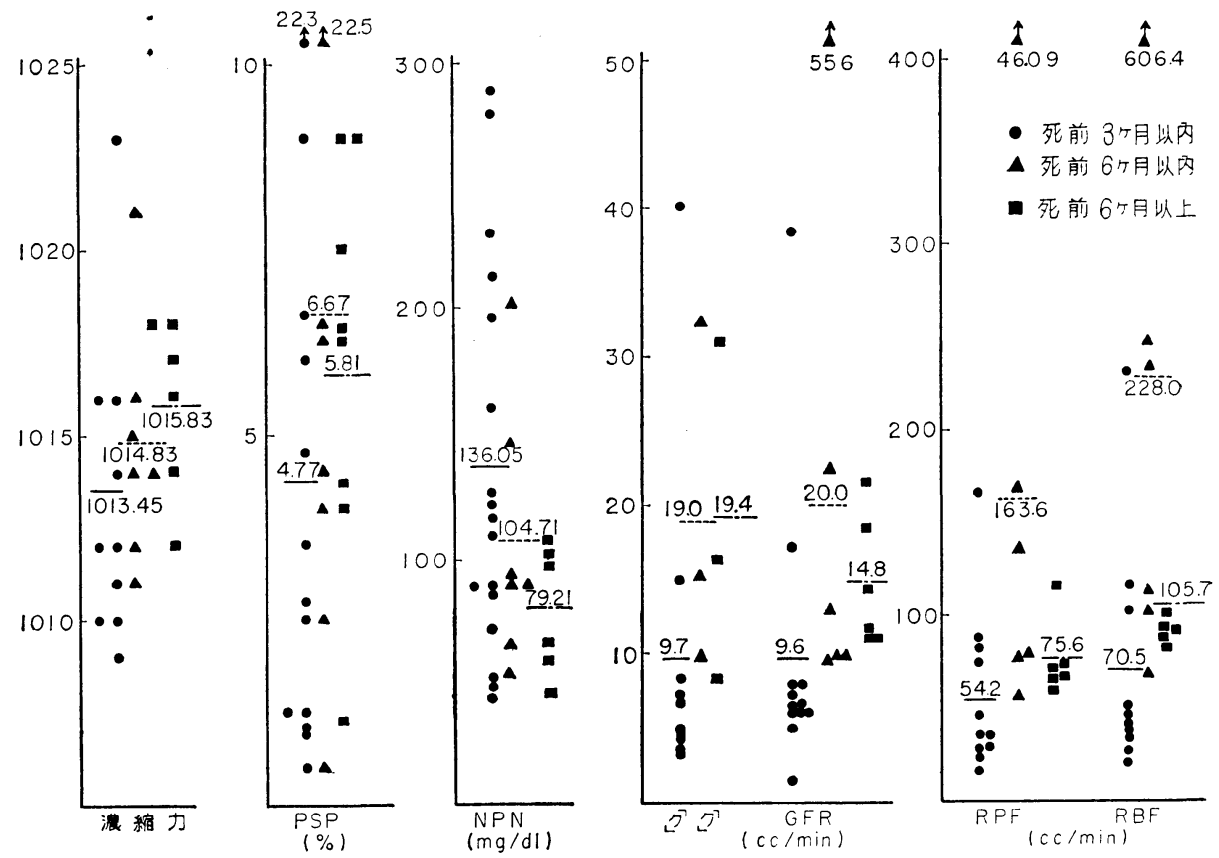

第 4 四末期腎患者の腎機能

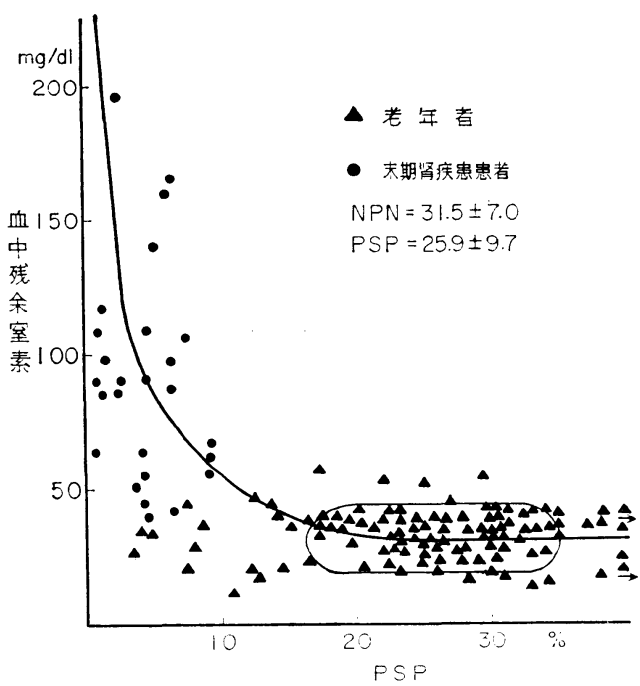

第 5 図PSP と血中残余窒素

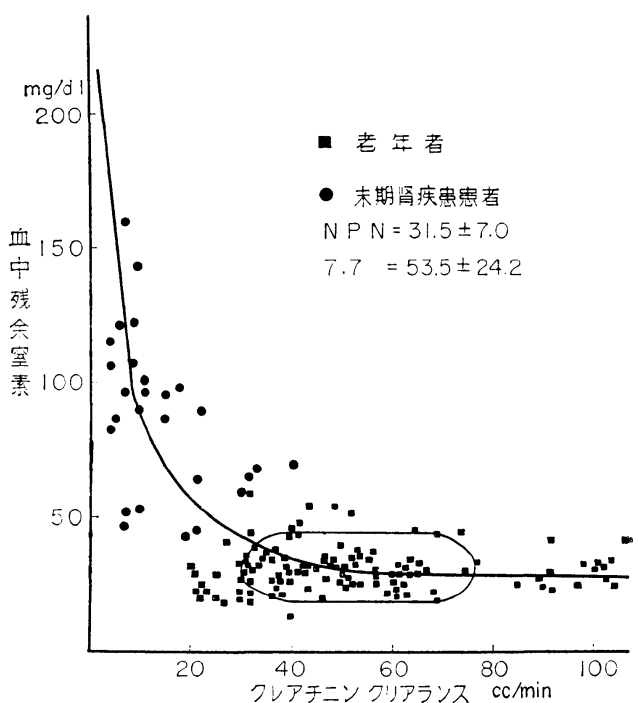

第 6 図クレアチニン・クリアランスと血中残余堂: 素 
した各種腎疾患者約 300 例のうちから，腎炎， 腎結核, 腎孟腎炎, その他腎疾患が増悪して死 亡した 31 例について，その死亡前 3 カ月以内， 6 力月以内, 6 力月以上にそれぞれ腎機能を行 つたものの腎機能は第 4 図の如くである。乞し て, 一般に血中残余窒素と PSP 排泄能, 或は 血中残余窒素とクレアチニンクリアランスとは 第 5 図及び第 6 図の曲線で示すよ5.な相関があ るものであるが，老年者の腎機能は低下してい るとは言つても図中楕円で囲んだ附近に集つて いて，上記の末期腎患者の腎機能が図中の丸点 附近にあることを思えば，生命の維持には遙か に余裕のあることを示している。

試みに, PSP, 尿濃縮力, 系球体濾過值の末 期にみられるような低值を横軸の基線にとり， 且つこれら三者の正常の下限値を同高になるよ うな目盛に座標をとつて, 前述した私達の回帰 方程式をこの座標上に言入してみると第 7 図の 如くなる。即ち，PSPは70 才くらいまでかな り正常範囲に保たれている人があるが，直線は 比較的急速に下降する傾向がある。系球体濾過 值濃縮力は, 既に 65 才で大部分正常の下限を

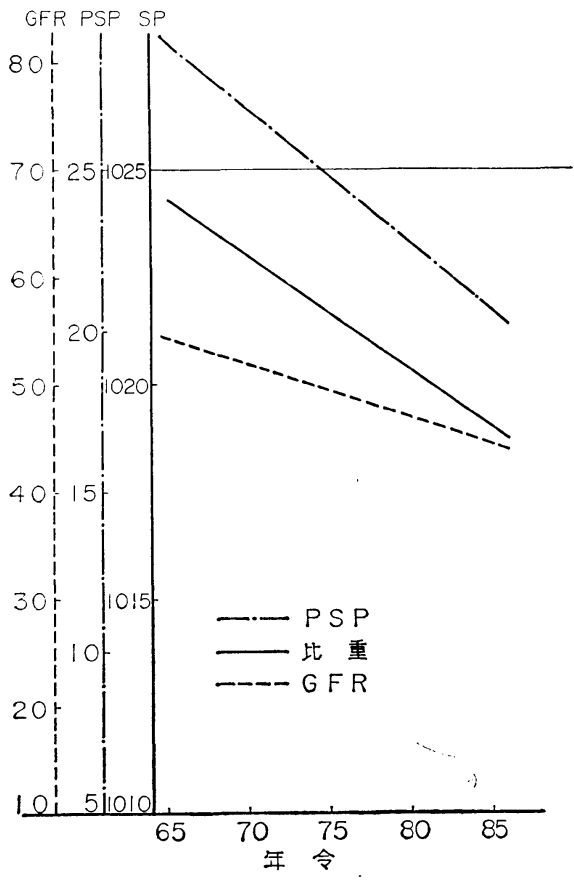

第 7 図 老年者の腎機能
切つているが，その直線の下降の度は比較的緩 徐である。仮にこれらの直線を延長して末期腎 状態の基線に交わる点を求めると, 大体 115 120 才くらいとなり, 従来我国の長寿者の記録 が男子 116 才女子 118 才であることを思い合 わせると興味深く感じられる。

\section{むすび}

私たちは, 福岡市近郊の須恵町の 65 才以上 の老人を対象とし, 腎機能を中心に血圧, 心電 図, 肝機能, 胃液酸度, 検尿, 検便々の他の臨 床検査を併せ行つた。この成績を整理して, 従 来私たちの経験に不足していた 65 才以上の老 年者の腎機能を検討補足していた。

そして，腎以外の身体徴候の関連に於て老年 者の腎機能を考察してみた。それによると年令 と腎機能に関連は認められるものの，極めてバ ラッキが大きく, 且つ他蔵器との関連は心電図 所見と多少の相関を示す他は, 個々の身体的徴 候で腎機能と関連を示すかにみえるるのは殆ん ぞなかつた。従つて, 老年者の腎機能は, 或る 特定の器官の衰退に特に影響をうけるというこ とは少く, 身体全体の老化と平行して一義的に 機能低下を示すもののようである。な执，私た ちの得た回帰方程式から末期腎状態に到る年令 を推定すると 115〜120 才となり，少くとも現 状に於て特に腎に何か特定の疾患でもない限 り，腎機能の年令的聥減が老年者の生命をおび やかすことはないものと思う。

\section{文献}

Conard, R. A. : J. of Gerontol. $15: 358,1960$

Davis, D. F.et al. : J. of Clin. Invest. $29: 496$, 1950

Howell, T. H. et al. : J. of Gerontol. $3: 124,1948$ Miller, J.H.et al. : J. of Gerontol. $8: 446,1953$

Surtshin, A. : J. of Gerontol. 12:161, 1957

Shock, N. W. : Cowdry's Problems of Ageing.

Williams and Wilkins, Baltimore, 1952, 3 rd. edition

Shock, N. W. : J. of Chronic Diseases, $2: 687$, 1955 